\title{
A kultúraváltás hatása az egyének készség- és képességrendszerére: új modellek
}

\section{Komplex modellek (mérési-értékelési-fejlesztési sztenderdek) a digitális környezetben való tevekénységekhez}

A szakirodalomban az elmúlt években több olyan összetett modell jelent meg, amelyek az információs müveltséget és az ehhez tartozó részkompetenciákat, készségeket, képességeket és tevékenységeket úgy foglalják keretbe, hogy az elektronikus tanulási környezet virtuális platformját, vagyis az internetet tekintik elsődleges terepnek, az analóg forrásokat és felületeket nem veszik figyelembe. $\mathrm{Az}$ alábbi elképzelések bemutatását azért tartom lényegesnek, mert ezáltal betekintést nyerhetünk abba, hogy az információs müveltségen túl milyen faktorokat tekintenek lényegesnek a digitális világban. Elöljáróban megállíthatjuk, hogy az információs müveltség (kimondva vagy kimondatlanul) mindegyikben tetten érhetö; illetve, lényegében egymással párhuzamosan, mindegyikben szinte azonos elemeket azonosítanak más-más elnevezések és kategóriák felhasználásával. 


\section{Digitális Kompetencia Értelmezésének Európai Keretrendszere (DIGCOMP)}

A DigComp (Digital Competence Framwork for Citizens) egy 2013-ban indult (Ferrari, 2013) kutatás, amely célul tủzte ki, hogy segítse a digitális (IKT-) kompetencia keretrendszerének megértését Európában. A tanulmány, majd a későbbi keretrendszer egy hosszas társadalmi egyeztetés eredménye, amely részletes keretet ad a digitális kompetenciáról minden európai polgár számára. A jelenlegi DIGCOMP a digitális kompetencia értelmezésének és fejlesztésének európai referenciakerete (EU Bizottság EUR $26035 \mathrm{~N}$ ), amely a digitális kompetenciák egységes értelmezését teszi lehetővé. A keretrendszernek 2016 nyarán új változata jelent meg.

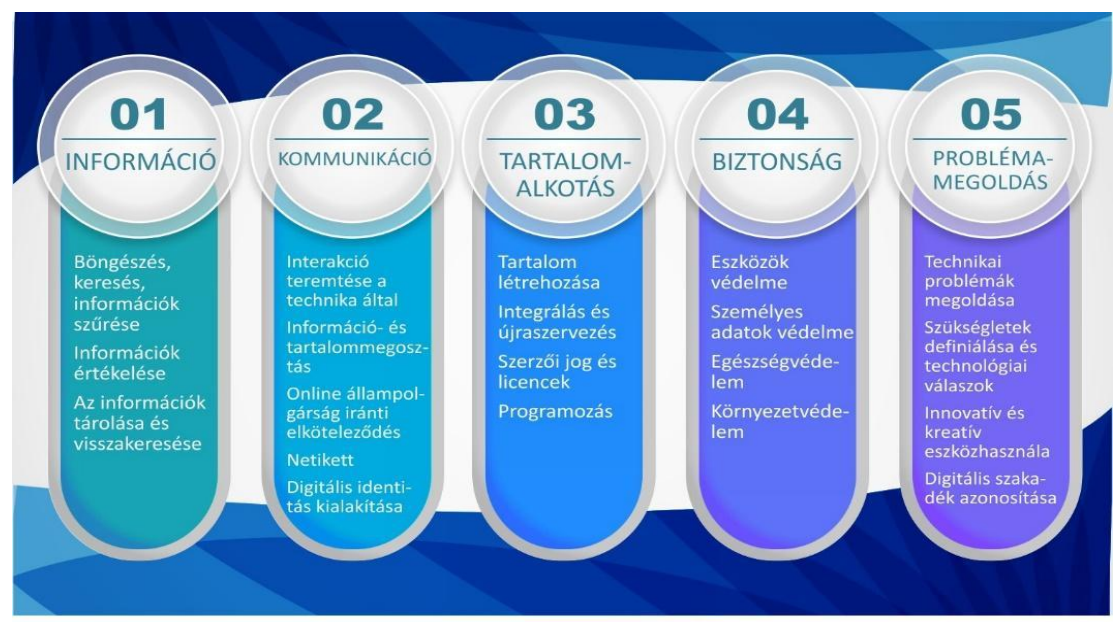

1. ábra A Digitális Kompetencia Értelmezésének Európai Keretrendszere az 5 dimenzió és a 21 kompetencia mentén (DIGCOMP) (Ferrari, 2013)

A DIGCOMP-keretrendszer két eszközt foglal magában: egy önértékelő eszközt, amely három jártassági szinten (A-szint: alapszint/alapszintű felhasználó; B-szint: középszint/önálló felhasználó; C-szint: felsőszint/felsőfokú felhasználó) értelmezi a digitális kompetenciát és szintleírások segítségével a felhasználó saját önértékelését teszi lehetővé. ${ }^{1}$ Emellett tartalmaz egy referenciakeretet, amely öt kompetencia-részterület (competence area) mentén definiálja a kapcsolódó digitális kompetenciákat. Mindegyik esetében általános meghatározást, a három jártassági szintnek megfelelő szintleírásokat, tudás-attitűd-képesség példákat,

\footnotetext{
${ }^{1}$ A DIGCOMP online önértékelési eszköze 2015. január 1-től elérhető az EUROPASS részeként.
} 
valamint különféle környezetben történő gyakorlati alkalmazási lehetőségeket mutat be (DIGCOMP, 2013). A kompetenciák általános, részletes leírása mellett a három jártassági szinten szintleírások, tudás-képesség-attitüd példák és gyakorlati alkalmazási lehetőségek is bemutatásra kerülnek. Három tudásszintet javasolnak minden kompetenciához, ${ }^{2}$ és egy fejlesztési indikátorrendszer segítségével mindenki meghatározhatja saját digitális kompetenciaszintjét. A keretrendszer 5 dimenzió (információ, kommunikáció, tartalom-létrehozás/készítés, biztonság, problémamegoldás) és 21 kompetenciaterület mentén valósult meg.

A DigComp egy másik eleme a DigCompOrg (Digitally-Competent Educational Organisations), ${ }^{3}$ azaz a digitálisan kompetens oktatási szervezetek keretrendszere, amely az intézmények digitális tudásszintjének mérésére szolgál (hasonlóan a magyar ELEMÉR rendszerhez), így a digitálisan kompetens intézmények keretrendszereként is aposztrofálható (Hunya, 2016). Ahogyan Hunya kiemeli, ezek olyan iránymutatásként szolgálhatnak az oktatáspolitikai folyamatok kialakításánál, illetve olyan viszonyítási alapot képezhetnek, mint a nyelvoktatásban a Közös Európai Referenciakeret (Hunya, 2016b).

A fogalomhoz köthető a globális állampolgárrá/állampolgári nevelés koncepciója, amelyet az UNESCO hívott életre, és számos fórumon támogatja a kezdeményezést. A globális állampolgárrá nevelés ugyanis átalakítja a gyerekek gondolkodását és egy igazságosabb, toleránsabb társadalmat hív életre. A globális állampolgárrá nevelés csak az oktatáson keresztül valósulhat meg, és egyben hozzájárul a békés társadalmak együttéléséhez.

\footnotetext{
${ }^{2}$ A kompetenciát a tudás, képesség, attitüd hármasaként írják le.

${ }^{3}$ „,A DigCompOrg keretrendszer a digitális korszakbeli hatékonytanulás támogatására való, ahol a tanulók (és általában az állampolgárok) digitális kompetenciáinak mérésére szolgáló. elkészült DigComp és a pedagógusok számára fejlesztés alatt álló DigComp Teachers rendszerrel alkot egy egységet. A keretrendszer 7 megnevezett, valamint egy 8. üres, ún. szektorspecifikus dimenzióból áll. A 7 dimenzió: a tanitás és tanulás gyakorlata; szakmai fejlödés; az értékelés gyakorlata; tanterv és tartalom; együttmüködés, hálózatosodás, infrastruktúra, vezetési gyakorlat. A hét dimenzió összesen 15 indikátor, az indikátorokhoz összesen 74, a mérési területek fejlettségét jellemzö mutató tartozik, amelyek bizonyos mértékü átfedésben vannak." (Hunya, 2016b, 38-39. o.)
} 


\section{Infokommunikációs Egységes Referenciakeret (IKER)}

Az IKER, vagyis az Infokommunikációs Egységes Referenciakeret 2015-2016ban került kifejlesztésre, ${ }^{4}$ az elsősorban gazdasági szempontból hátrányos helyzetú társadalmi csoportok felzárkóztatása és a digitális kulcskompetenciáik ${ }^{5}$ fejlesztése céljából, valamint annak érdekében, hogy gazdasági versenyképességük növekedjen, munka-erőpiaci esélyeik javuljanak. Részei egy infokommunikációs egységes referenciakeret ${ }^{6}$ és egy önértékelési rendszer, amelyek a nemzetközi és az európai közösség ajánlásaihoz illeszkednek és lehetővé teszik a digitális kompetencia fejlesztését az IKT-eszközök ${ }^{7}$ segítségével, valamint az egyén önértékelését ezen a területen.

A nemzetközi referenciakeret (DIGCOMP-keretrendszer) alapján lehetővé teszi az egyén számára, hogy saját digitális kompetenciaszintjét meghatározza, és mivel a rendszer egységesen értelmezi a digitális készségeket, lehetővé teszi ezek azonos célkitüzések mentén történő fejlesztését. A DigComp rendszerének átültetése hazai környezetbe a magyar sajátosságok miatt nem volt kivitelezhető, ez indokolta egy új rendszer kidolgozását.

Az IKER rendszerben minden szint magában foglalja az alatta lévő szintet, amelyek 1-4-ig kerültek meghatározásra. A felhasználó az ismerttől, megszokottól és az egyszerütől halad az ismeretlen, váratlan, bonyolult felé a tudás, képesség, attitüd, autonómia ${ }^{8}$ és felelősség részterületek mentén (IKER, 2016b) (1. sz. melléklet).

${ }^{4}$ A GINOP 6.1.2. Digitális szakadék csökkentése pályázat keretében, a Nemzeti Szakképzési és Nemzetgazdasági Hivatal vezetésével.2015-től 2017-ig tart.

URL: http://emagyarorszag.hu/iker-workshop-2016-04-12/

${ }^{5} \mathrm{~A}$ digitális kompetencia alatt az alábbi meghatározást értik: A digitális kompetencia magában foglalja az információs társadalmi technológiák magabiztos és kritikus használatát a munka, a szabadidő és a kommunikáció terén. Ez az IKT terén meglévő alapvető készségeken alapul: számítógép használata információ visszakeresése, értékelése, tárolása, előállítása, bemutatása és cseréje céljából, valamint a kommunikáció és az együttmüködő hálózatokban való részvétel céljából az interneten keresztül. (2006/962/EK)

${ }^{6}$ Az IKT kompetenciák fejlesztése párhuzamosan történik a nyelvi kompetenciákkal, így a referenciakeret szintjei a KER szintjeihez igazodtak. Az IKER 1. és 2. szintje a DIGCOMP A (alapszint), a 3. és 4. szintje a DIGCOMP B (középszint) kategóriáiba kerül besorolásra.

7 Infokommunikációs technológiák (IKT): olyan eszközök, eljárások, innovatív folyamatok összessége, amelyek az információközlést, feldolgozást, annak áramlását és kódolását hatékonyabbá és gyorsabbá teszik.

${ }^{8}$ A tudás, képesség, attitüd hármasa a klasszikus kompetenciaalkotó elemek, a DIGCOMP is ezt a három összetevőt tartja a kompetencia alapjának. 


\section{Digitális intelligencia: készségek a sikeres digitális élethez ${ }^{9}$}

A digitális intelligencia fogalma már évekkel ${ }^{10}$ ezelőtt megjelent a köztudatban, bár sok esetben a digitális kompetenciát értik alatta, és mérése elsősorban az üzleti életben terjedt el. A digitális IQ (digital intelligence - DQ) fogalmának éltre hívását több nemzetközi technológiai trenddel indokolják. Egyrészt a világ teljes populációjának 90\%-a 10 éven belül bekapcsolódik az internet vérkeringésébe, másrészt a mai gyerekek átlagosan 7 órát töltenek naponta képernyő előtt; mindez jelentős változásokat idéz elő az oktatásban is. Megjelenik az életkori szakadék problémája is a felnőttek és tanulók között, a digitális technológia eszközeit illetően. ${ }^{11}$

A DQ fogalmát a következőképpen definiálják: egy olyan szociális, érzelmi és kognitív készségekből álló készlet, amely lehetővé teszi az egyének számára, hogy szembenézzenek a kihívásokkal és alkalmazkodni tudjanak a digitális élet igényeihez és elvárásaihoz (Yuhyun, 2016).

Ez a 8 készségből álló gyüjtemény (készlet) a digitális közeg kihívásainak leküzdéséhez és a digitális lét szükségleteinek kielégítéséhez szükséges tudást, készségeket és képességeket foglalja magában; olyan módon, hogy az egyén érzékelje mások érzéseit és alkalmazkodjon azokhoz, valamint adott esetben adaptív módon szabályozza mások viselkedését. A digitálisan intelligens embereknek a technológiai, tárgyi tudás és ismeretek mellett alapvető emberi értékekkel is rendelkezniük kell, például tisztelettel, tisztességgel, empátiával és

${ }^{9}$ Az alcím Farkas Bertalan Péter Tér-idő blogon megjelent bejegyzéséből származik (Farkas, 2016).

${ }^{10}$ A Digitális IQ ${ }^{\circledR}$ mérést 2007 óta végzi egy amerikai szervezet, a PWC. A válaszadók köre az informatikai és üzleti vezetőkből kerül ki. A mérés célja a versenyszférában a technológia általi profitnövelés lehetőségeinek feltérképezése 10 kritikus digitális témán keresztül, amely során azt mérik, hogy az üzleti vezetők digitális IQ-ja milyen fejlettségi szintü. Megállapították ugyanis, hogy a magas digitális IQ-val rendelkező vezetők kétszer nagyobb arányban és gyorsabban érnek el a vállalaton belül profitnövekedést, mint a lemaradók. A legutóbbi (2015-ös) mérésben a világ 6 régiójából (Észak-Amerika, Latin-Amerika, Nyugat-Európa, Közép- és Kelet-Európa, Ázsia, Afrika és a Közel-Kelet), 10 iparágból érkeztek válaszok. Bővebben: http://www.pwc.com/gx/en/services/advisory/2015-global-digital-iq-survey.html

${ }^{11}$ Hozzá kell tenni, hogy nem új keletű jelenségről van szó, hiszen a Prensky (2001) által életre hívott digitális bennszülött és bevándorló fogalmát, valamint ezek különböző változatait (Google-nemzedék, netgeneráció stb.) számos publikációban tetten érhettük az elmúlt évtizedben. Azt is megállapították, hogy nem az életkor a döntő tényező a digitális kompetenciában, tehát a mai generáció nem nevezhető digitális bennszülöttnek. Fejlesztésük és képzésük elengedhetetlenül szükséges. Az újabb szakirodalmak napjainkban már alfa-generációról beszélnek. 
megfontoltsággal, hiszen ezek az analóg mellett a digitális világban is alapvető értékek. A DQ filozófiája szerint 8 készség szükséges ahhoz, hogy sikeresek legyünk a digitális világban (Farkas, 2016) (2. ábra).

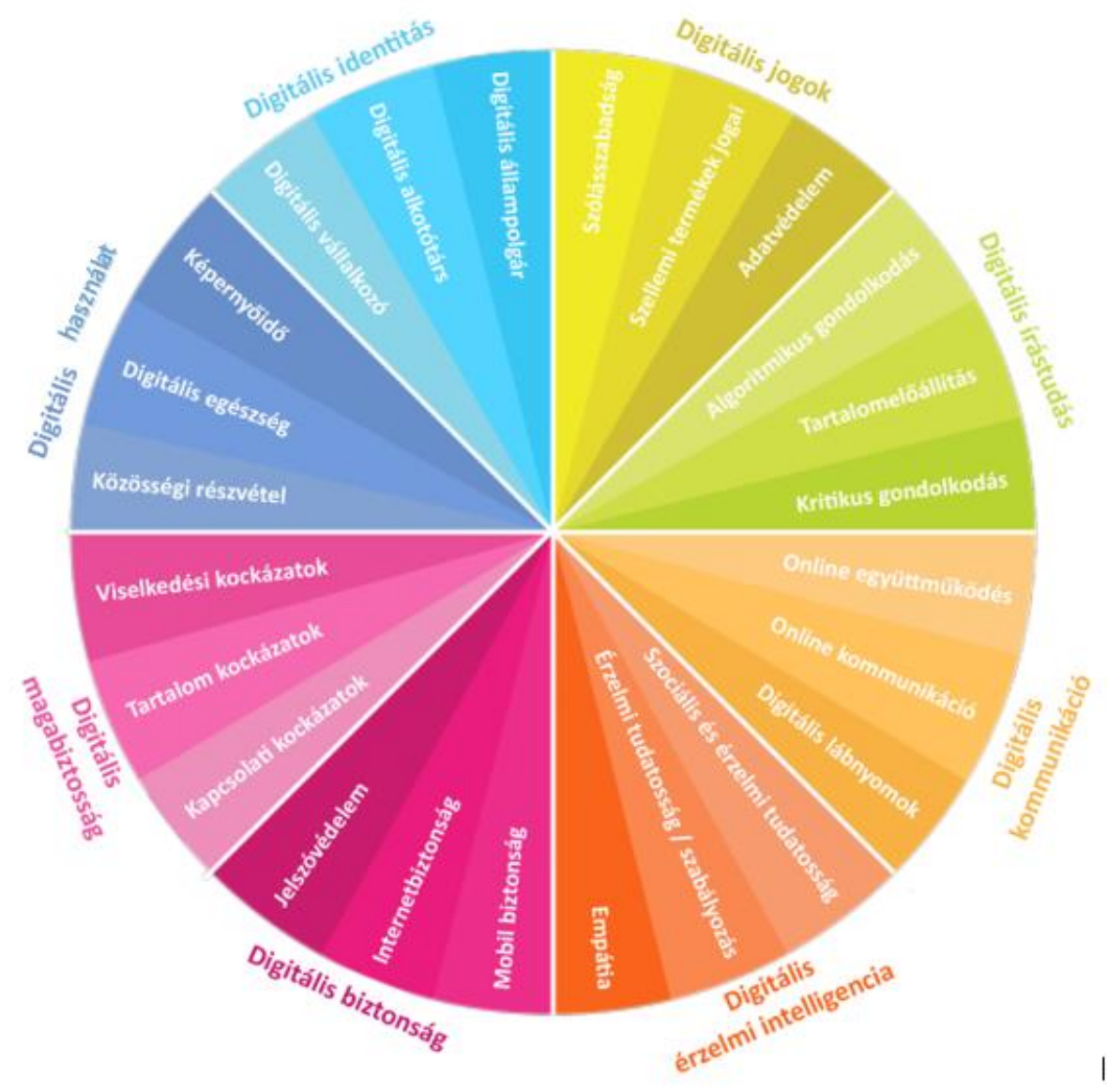

2. ábra A DQ elemei (fordítás és ábra: Farkas, 2016) ${ }^{12}$

A DQ 8 terület köré szerveződik, három szinten: digitális állampolgárság, digitális kreativitás és digitális vállalkozás.

A digitális állampolgárság lényegében a digitális vezetőkészségekben teljesedik ki, ezek révén sajátítja az egyén azt a készséget, amely révén a technológiai környezetben magabiztos, felelős és hatékony felhasználó lesz. Fontos elem a kreatív attitüd, hiszen a digitális környezetben a tanuló partner és alkotótárs (társszerző) is, aki kreatív médiahasználattal, a technológia és a médiaeszközök

\footnotetext{
12 A szerző a hivatkozott magyar nyelvü ábrán szereplő digitális egyensúly helyett a digitális használat kifejezést alkalmazza.
} 
alkalmazásával valósítja meg ötleteit. A legmagasabb szint a vállalkozó szint, amelynek keretében a tanuló az előbbi két szint készségeinek birtokában képes a problémamegoldásra és feladatok összetett megoldására. 


\section{1. táblázat A DQ területei}

\begin{tabular}{|c|c|c|}
\hline \multirow{3}{*}{$\begin{array}{l}\text { Digitális } \\
\text { használat } \\
\text { (digital use) }\end{array}$} & \multirow{3}{*}{$\begin{array}{l}\text { A digitális eszközök és média } \\
\text { használatának képessége, amely } \\
\text { magában foglalja, az egészséges } \\
\text { összhang megtalálását és } \\
\text { kontrollját az online és az offline } \\
\text { lét között. }\end{array}$} & $\begin{array}{l}\text { képernyő előtt töltött idő } \\
\text { (screen time) }\end{array}$ \\
\hline & & $\begin{array}{l}\text { digitális egészség (digital } \\
\text { health) }\end{array}$ \\
\hline & & $\begin{array}{l}\text { közösségi részvétel } \\
\text { (community participation) }\end{array}$ \\
\hline \multirow{3}{*}{$\begin{array}{l}\text { Digitális } \\
\text { védelem }^{13} \\
\text { (digital safety) }\end{array}$} & \multirow{3}{*}{$\begin{array}{l}\text { Az internetes veszélyek } \\
\text { kezelésének képessége } \\
\text { (internetes zaklatás - } \\
\text { cyberbulling; becserkészés - } \\
\text { grooming; szélsőségessé válás - } \\
\text { radikalizáció) és a veszélyes } \\
\text { (erőszakos, obszcén) online } \\
\text { tartalmaktól való óvakodás, } \\
\text { valamint az ezekkel való } \\
\text { találkozások számának } \\
\text { csökkenése. }\end{array}$} & $\begin{array}{l}\text { viselkedési kockázatok } \\
\text { (behavioral risks) }\end{array}$ \\
\hline & & $\begin{array}{l}\text { tartalmi kockázatok (content } \\
\text { risks) }\end{array}$ \\
\hline & & $\begin{array}{l}\text { kapcsolati kockázatok } \\
\text { (contact risks) }\end{array}$ \\
\hline \multirow{3}{*}{$\begin{array}{l}\text { Digitális } \\
\text { biztonság } \\
\text { (digital security) }\end{array}$} & \multirow{3}{*}{$\begin{array}{l}\text { A kibertámadások } \\
\text { felismerésének képessége, illetve } \\
\text { a jó gyakorlatok és biztonsági } \\
\text { eszközök, alkalmazások ismerete } \\
\text { és használata az adatok védelme } \\
\text { érdekében. }\end{array}$} & jelszóvédelem \\
\hline & & internetes biztonság \\
\hline & & mobilbiztonság/mobilvédelem \\
\hline \multirow{3}{*}{$\begin{array}{l}\text { Digitális érzelmi } \\
\text { intelligencia } \\
\text { (digital } \\
\text { emotional } \\
\text { intelligence) }\end{array}$} & \multirow{3}{*}{$\begin{array}{l}\text { Az empatikus viselkedés és a } \\
\text { másokkal való jó kapcsolat } \\
\text { kiépítése az online közegben. }\end{array}$} & empátia (empathy) \\
\hline & & $\begin{array}{l}\text { érzelmi tudatosság / } \\
\text { szabályozás } \\
\text { (emotional } \\
\text { awareness/regulation) }\end{array}$ \\
\hline & & $\begin{array}{l}\text { társadalmi és érzelmi } \\
\text { tudatosság } \\
\text { (social and emotional } \\
\text { awareness) }\end{array}$ \\
\hline
\end{tabular}

${ }^{13}$ Farkas (2016) a digitális egyensúlyt használja a digital safety és a digital security gyüjtőfogalmaként, illetve felveti a digitális magabiztosság fogalmát, szintén ehhez a két fogalomhoz. 


\begin{tabular}{|c|c|c|}
\hline \multirow{3}{*}{$\begin{array}{l}\text { Digitális } \\
\text { kommunikáció } \\
\text { (digital } \\
\text { communication) }\end{array}$} & \multirow{3}{*}{$\begin{array}{l}\text { A digitális technológia és média } \\
\text { használata által történő } \\
\text { kommunikáció és együttmüködés } \\
\text { képessége. }\end{array}$} & $\begin{array}{l}\text { digitális lábnyomok (digital } \\
\text { footprints) }\end{array}$ \\
\hline & & $\begin{array}{l}\text { online kommunikáció (online } \\
\text { communication) }\end{array}$ \\
\hline & & $\begin{array}{l}\text { online együttmüködés (online } \\
\text { collaboration) }\end{array}$ \\
\hline \multirow{3}{*}{$\begin{array}{l}\text { Digitális } \\
\text { műveltség } \\
\text { (digital literacy) }\end{array}$} & \multirow{3}{*}{$\begin{array}{l}\text { Az információ megtalálásának, } \\
\text { értékelésének, hasznosításának, } \\
\text { megosztásának, illetve a } \\
\text { tartalmak létrehozásának } \\
\text { képessége a számítógépes } \\
\text { problémamegoldással együtt. }\end{array}$} & $\begin{array}{l}\text { kritikus gondolkodás (critical } \\
\text { thinking) }\end{array}$ \\
\hline & & $\begin{array}{l}\text { tartalomlétrehozás (contect } \\
\text { creation) }\end{array}$ \\
\hline & & $\begin{array}{l}\text { számítógépes } \\
\text { problémamegoldás, } \\
\text { algoritmikus gondolkodás } \\
\text { (computational thinking) }^{14}\end{array}$ \\
\hline \multirow{3}{*}{$\begin{array}{l}\text { Digitális jogok } \\
\text { (digital rights) }\end{array}$} & \multirow{3}{*}{$\begin{array}{l}\text { A személyes és szerzői jogok } \\
\text { megértésének és betartásának } \\
\text { képessége, amelynek része a } \\
\text { magánélethez való jog, a } \\
\text { szellemi tulajdon védelme, a } \\
\text { szólásszabadság, illetve a } \\
\text { gyülöletbeszéd elleni védelem. }\end{array}$} & $\begin{array}{l}\text { véleményszabadság, } \\
\text { gondolatok szabadsága } \\
\text { (freedom speech) }\end{array}$ \\
\hline & & $\begin{array}{l}\text { szellemi tulajdonjogok } \\
\text { (intellectual property rights) }\end{array}$ \\
\hline & & magánélet (privacy) \\
\hline \multirow{3}{*}{$\begin{array}{l}\text { Digitális } \\
\text { identitás } \\
\text { (digital identity) }\end{array}$} & \multirow{3}{*}{$\begin{array}{l}\text { A saját online identitás és hírnév } \\
\text { kiépítésének, kezelésének } \\
\text { képessége, valamint mások } \\
\text { tisztelete. Magában foglalja az } \\
\text { online személyiséget, az online } \\
\text { jelenlétet és magatartást, illetve } \\
\text { annak menedzselését rövid és } \\
\text { hosszú távon. }\end{array}$} & $\begin{array}{l}\text { digitális állampolgár (digital } \\
\text { citizen) }\end{array}$ \\
\hline & & $\begin{array}{l}\text { digitális társszerző (digital co- } \\
\text { creator) }\end{array}$ \\
\hline & & $\begin{array}{l}\text { digitális vállalkozó (digital } \\
\text { enterpreneur) }\end{array}$ \\
\hline
\end{tabular}

A DQ projekt egy olyan, a digitális intelligenciát középpontba állító nyílt kezdeményezés, amely egy elméleti modell pilot kísérletek formájában való igazolását tüzte ki célul, elsősorban a délkelet-ázsiai országok együttműködésével. 2016 júniusában indult, eddig 14 ország bevonásával. A projekt jelenleg (2016. július) kísérleti fázisában van. A modell egy online

14 Farkas (2016) bejegyzésében az algoritmikus gondolkodást használja az angol computational thinking fordításaként. 
tananyagcsomaggal is kiegészül, amely a 9-12 éves korosztálynak, 8 témában 50 online leckét kínál a digitális vezetés (digital leadership) témakörben (1. táblázat).

Ezenkívül egy online mérési-értékelési eszköz is rendelkezésre áll. A teszt kitöltésével elkészül a kitöltő személyes DQ-profilja, amely tartalmazza a tanuló pontszámát az adott területen, az összpontszámot, a mérésben részt vevő országok átlagát és a fejlesztési feladatokat a továbblépéshez ${ }^{15}$ (3. ábra).



3. ábra A DQ-teszt eredményének megjelenítése

Forrás: http://www.dqproject.org/what-is-dq/\#platform

${ }^{15}$ Hazánkban hasonló, bár szélesebb korosztálynak szól az Infokommunikációs Egységes Referenciakeret (IKER), amely célja a digitális készségek szintjének meghatározása. Az IKER, amely a már széles körben a nyelvtudás szintjének mérésére használt KER, a Közös Európai Referenciakeret mintájára készült, az informatikai írástudás 4 szintjét különbözteti meg. Az IKER a tanulási eredmények (learning outcoming) - a tudás, a képesség, az attitüd, az autonómia és a felelősség - szempontrendszeréből kiindulva összesen 5 téma köré csoportosítja az egyén digitális kompetenciáit: 1. az információ gyüjtése; felhasználása, tárolása; 2. digitális, internet alapú kommunikáció; 3. digitális tartalmak létrehozása; 4. problémamegoldás, gyakorlati alkalmazás; 5. IKT-biztonság. Forrás: Rákosi Szilvia: Infokommunikációs Egységes Referenciakeret, azaz IKER. https://ec.europa.eu/epale/hu/blog/rakosi-szilvia-infokommunikacios-egysegesreferenciakeret-azaz-iker 
Összességében megállapíthatjuk, hogy a DQ hasonló céllal jött létre mind a versenyszféra, mind az oktatás számára; hiszen a cél az, hogy digitális tudatos egyéneket (állampolgárokat) neveljünk, akik a későbbiekben hasonló szemléletű vezetővé válnak.

\section{A 21. századi képességek átfogó modellje a digitális környezetben: a webmúveltség sztenderd (MOZILLA) ${ }^{16}$}

A webmüveltség sztenderdje/modellje összefogja a 21. századi készségek és képességek (21 C Skills) új keretét, és kulcsszerepet játszik azok fejlesztésében állapítják meg a sztenderd kidolgozói. Lényegében azt mondhatjuk, hogy ebben az esetben (is) az információs müveltség modelljének egy újabb értelmezésével találkozunk, amely az alapkészségek oldaláról közelíti meg a kérdést és a webes platformot helyezi előtérbe.

A webmüveltség sztenderdjének alapgondolata, hogy digitális világban (platformon) való olvasás, írás és részvétel a 4. alapkészséggé vált, a korábbi írásolvasás-számolás mellett. Emellett a fejlesztők jelentős problémaként említik, hogy nincs egységes konszenzus abban, mit értünk az egyes fogalmak (webmüveltség, médiaműveltség, információs müveltség) alatt, azok között jelentős átfedés tapasztalható, így meglehetősen nehezen beépíthetők az oktatásba, a tantervekbe.

A fejlesztés során létrehoztak egy ún. webműveltség-térképet, ${ }^{17}$ egy kompetenciarácsot, amelynek 3 területén a felfedezés (a weben való eligazodás), az építés (alkotás/létrehozás a weben) és az összekapcsoltság (részvétel a weben) komponenseit határozták meg, elsősorban a webre mint fejlesztő közegre fókuszálva. Ezt a kompetenciarácsot ajánlásnak szánják,

16 Cathy Davidson, a Mozilla Alapítvány igazgatója 2012-ben a következőképpen fogalmazta meg missziójukat: „A világunk 1993 áprilisában megváltozott a Mosaic 1.0 böngésző megjelenésével a nagyközönség számára. Az oktatásban új módszereket kell bevezetnünk. Meg kell reformálni az oktatási intézményeket, a koncepciót és az értékelés módjait. Ma mindenki, aki eléri a világhálót $(W W W)$, a passzív fogyasztói modellböl a web tartalmainak létrehozójává válik. Személyre szabhatjuk, ujjászervezhetjük a tartalmat, csinálhatjuk ezt egyedül vagy másokkal együttmüködve, bárhol a világban, a weben keresztül. Ez a „csináld magad” mód lehetöséget teremt, a hálózaton és részvételen alapuló, improvizációs tanulás új készségeket követel, amelyet nevezhetünk új müveltségnek.” Az 1998-ban alakult Mozilla Alapítvány célja a webes müveltség fejlesztése, amely során döntéshozókkal, tanárokkal és informatikai szakemberekkel együttmüködve segít az internetet megismerhetővé (megérthetővé), átjárhatóvá (lehetőségeket bemutatóvá, innovációt elősegítővé) és közössé(givé) (mindenki számára nyitottá) tenni.

${ }^{17}$ A koncepcióról bővebben lásd: http://mozilla.github.io/webmaker-whitepaper/ 
érzékeltetve, hogy egy összetett, a készségeket, képességeket és kompetenciákat egyesítő területről van szó.

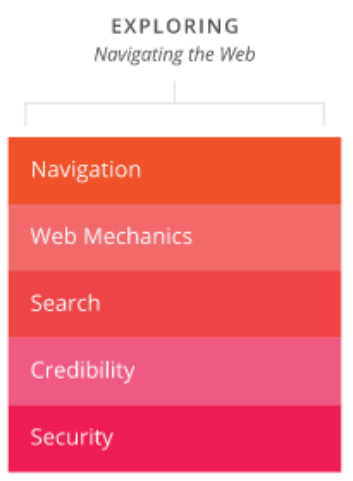

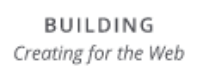

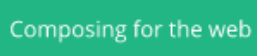

Remixing

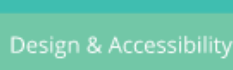

Coding/Scripting

Infrastructure
CONNECTING
Participating on the Web

Sharing

Collaborating

Community Participatior

Privacy

Open Practices

\section{m. Webmaker}

4. ábra A webmüveltség térkép (kompetencia rács) (Web-literacy map)

URL: http://mozilla.github.io/webmaker-whitepaper/

A webre mint platformra tekintenek, amely révén céljuk, hogy a webes ökoszisztéma az innovatív fejlesztéseket elősegítse és részt vegyen a kollaboratív jövő kialakításában. Úgy vélik, hogy a webes platform kibővítette lehetőségeinket, és a hálózatosodott világban a hozzáférés, a tér- és időfüggetlen tanulás új távlatokat nyitott. Nagy jelentőséget tulajdonítanak a programozásnak, és úgy vélik, hogy az alapkészségek (írás, olvasás, számolás) mellett az algoritmus lesz a 4R új eleme. ${ }^{18}$

Ha ezt kombináljuk a 21. századi vezetői képességekkel (kritikus gondolkodás, együttmüködés, problémamegoldás, kreativitás és kommunikáció), versenyképesek leszünk. Az, hogy a használók milyen mértékben és szinten képesek az adott környezet lehetőségeit kihasználni, vagyis a tartalmakat elolvasni, feldolgozni, szintetizálni, értékelni és másokkal megosztva továbbítani, nagyban determinálja digitális létünk és mindennapi életünk hatásfokát.

${ }^{18}$ Erről bővebben lásd:

Davidson, C.N. (2012). Why we need a 4th R: Reading, wRiting, aRithmetic, algoRithms.

DMLcentral.

URL: https://goo.gl/9k18xE (utolsó megtekintés: 2016. június 10.)

Davidson, C.N. és Goldberg, D.T. (2010). The Future of Thinking: Learning Institutions in a Digital Age. Cambridge, MA: The MIT Press. The John D. and Catherine T. MacArthur Foundation Reports on Digital Media and Learning. URL: https://goo.gl/wH2NAM (utolsó megtekintés: 2016. június 10.) 
A kulcskészségek a következők:

- Olvasás: az interneten való kutatás módozatai. Alapvető internetismeretek. A tartalom értékelése, tudatos és kritikus tartalomkiválasztás.

- Írás: a webes tartalmak előállításának ismerete. Tartalmak újraalkotása, remixelése.

- Részvétel: a másokkal való kommunikáció és kapcsolatteremtés az interneten, valamint a biztonságos internethasználat ismerete, az online identitás és digitális önvédelem (pl. csalások elkerülése).

A 21. századi készségek az ismeretek, készségek, munkavégzési szokások és személyiségbeli jellemvonások tág együttesei, amelyek elengedhetetlenek napjainkban a tanulás és a munka terén. Ide tartozik az együttmüködés, a kommunikáció, a kreativitás és a problémamegoldás is.

Egy olyan többdimenziós modellt dolgoztak ki a webmüveltség sztenderdjének keretében, amelyben a három kulcskészséghez (írás, olvasás, részvétel) tevékenységek/tudáselemek kapcsolódnak, kiegészülve a 21. századi müveltségelemekkel, amelyeket az ábrán színes vonalakkal jelölnek és több elemi tevékenységre osztanak. Mindegyik tevekénységhez feladatok kapcsolódnak, amelyek különböző nehézségüek, illetve megoldásuk eltérő felkészültségi szintet és időráfordítást kíván (5. ábra) (2. táblázat). 


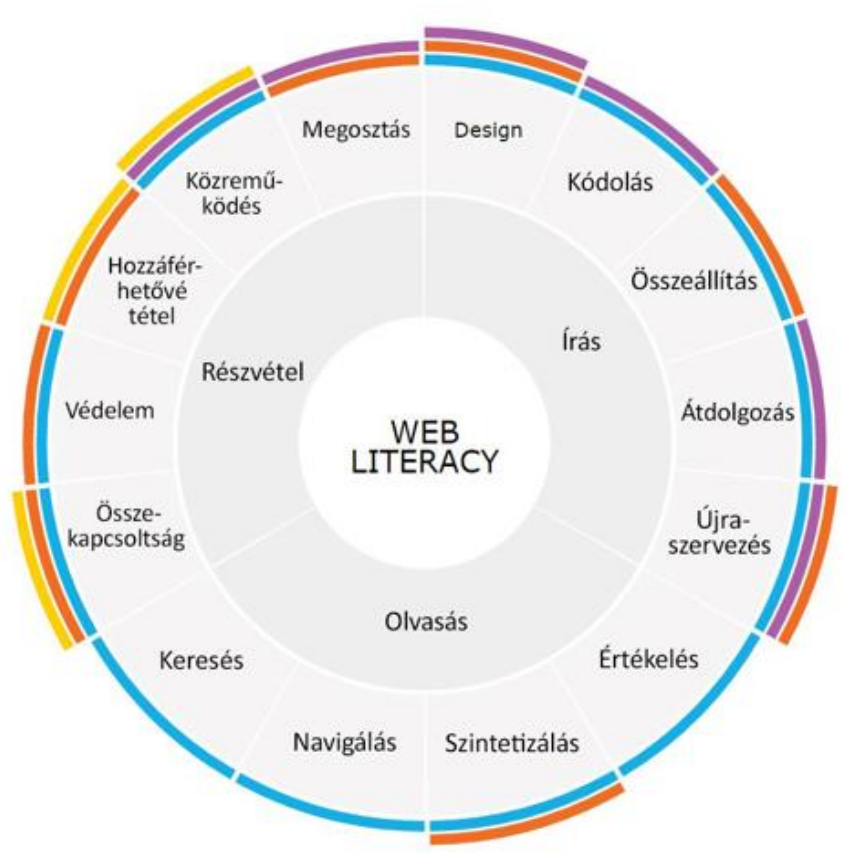

• Problémamegoldás

マ Kommunikáció

ॠreativitás

Együttmüködés

5. ábra A webmüveltség elemei (a szerző saját fordítása)

(A Web Literacy 2.0. URL: http://mozilla.github.io/content/web-lit-whitepaper/\#webliteracy-skills forrás alapján)

Az írás kulcskészség, amely által az egyén képessé válik az interneten lévő tartalmak létrehozására és saját vélemények megosztására. Ezáltal sokszor új müfajok jönnek létre, a tartalmak remixelése révén. A tartalom-létrehozás módjának megtanulása a tevékenység végzése közben valósul meg, tehát a felfedezéses és más tevékenységekbe ágyazott tanulás módszerének alkalmazásával. ${ }^{19} \mathrm{Az}$ ehhez tartozó webmüveltség-elemek: design, kódolás, összeállítás, átdolgozás és újjászervezés. Az ehhez a kulcskészséghez kapcsolódó 21. századi képességek: problémamegoldás, kommunikáció, kreativitás és együttmüködés.

Az olvasás kulcskészség, az online tartalmak kritikus és tudatos fogyasztását, értékelését jelenti (vö. NAT, tudatos és kritikus médiahasználat és médiamüveltség); a weben történő felfedezést és eligazodást egyaránt magában foglalja. Hasonlóan a hagyományos szövegolvasásához, ahol követelmény a szövegértés és a nyomtatott szöveg koncepciójának ismerete, a web müködésének

${ }^{19}$ Vö. digitális állampolgárság modell digitális értékteremtés; digitális produktivitás; digitális tartalomszervezés. 
alapvető ismerete itt is elvárás (pl. link, hiptertext). ${ }^{20} \mathrm{Az}$ ehhez tartozó webmüveltség-elemek: keresés, navigálás, szintetizálás, értékelés. Az ehhez a kulcskészséghez kapcsolódó 21. századi képességek: problémamegoldás, kommunikáció, kreativitás.

A legösszetettebb a részvétel kulcskészség (és annak elemei), amely lényegében a nyitott webes közegben megvalósuló közösségi kommunikációt, a tartalmak megosztását és létrehozását jelenti. ${ }^{21} \mathrm{Az}$ egészséges online kommunikáció megköveteli annak ismeretét, hogy miként kell tartalmat alkotni és azt nyilvánossá tenni (publikálni), illetve tartalmazza a biztonsági kérdéseket, úgy mint az identitásunk megóvását és megőrzését (vö. digitális állampolgárság modell digitális énmegjelenítés). Az ehhez tartozó webmüveltség-elemek: összekapcsoltság, védelem, hozzáférhetővé tétel, közreműködés és megosztás. Az ehhez a kulcskészséghez kapcsolódó 21. századi képességek: problémamegoldás, kommunikáció, kreativitás és együttműködés.

20 Vö. digitális állampolgárság modell digitális hozzáférés; digitális kommunikáció; digitális értékteremtés; digitális produktivitás; digitális tartalomszervezés.

21 Vö. digitális állampolgárság modell digitális hozzáférés; digitális kommunikáció; digitális egészség digitális én-megjelenítés; digitális együttélés; digitális értékteremtés; digitális produktivitás; digitális tartalomszervezés. 
2. táblázat A webmüveltség-sztenderd elemei (a szerzö saját fordítása) URL: (http://mozilla.github.io/content/web-lit-whitepaper/\#web-literacy-skills)

\begin{tabular}{|c|c|c|}
\hline Írás (Write) & Olvasás (Read) & Részvétel (Participate) \\
\hline $\begin{array}{l}\text { design (Design) } \\
(21 . \text { századi készségek: } \\
\text { kreativitás, } \\
\text { problémamegoldás, } \\
\text { kommunikáció) }\end{array}$ & $\begin{array}{l}\text { keresés (Search) } \\
\text { (21. századi készség: } \\
\text { problémamegoldás) }\end{array}$ & $\begin{array}{l}\text { összekapcsoltság } \\
\text { (Connect) } \\
\text { (21. századi készségek: } \\
\text { problémamegoldás, } \\
\text { együttműködés, krea- } \\
\text { tivitás, kommunikáció) }\end{array}$ \\
\hline $\begin{array}{l}\text { A mentális és fizikai } \\
\text { reprezentációk létrehozása } \\
\text { a digitális tartalmak } \\
\text { hozzáférhetösége és } \\
\text { elérhetősége } \\
\text { szempontjából (vizuális } \\
\text { elrendezés, } \\
\text { tartalomkiemelés). }\end{array}$ & $\begin{array}{l}\text { Kérdések feltevésével és } \\
\text { kulcsszavak segitségével a } \\
\text { szükséges információk } \\
\text { megtalálása. }\end{array}$ & $\begin{array}{l}\text { A problémamegoldás } \\
\text { területén a tanulók } \\
\text { látókörének szélesitése a } \\
\text { közösségi hálózatok és } \\
\text { eszközök révén. }\end{array}$ \\
\hline $\begin{array}{l}\text { kódolás (Code) } \\
\text { (21. századi készségek: } \\
\text { problémamegoldás, } \\
\text { kommunikáció) }\end{array}$ & $\begin{array}{l}\text { navigálás (Navigate) } \\
\text { (21. századi készség: } \\
\text { problémamegoldás) }\end{array}$ & $\begin{array}{l}\text { védelem (Protect) } \\
\text { (21. századi készségek: } \\
\text { kreativitás, } \\
\text { problémamegoldás, } \\
\text { kommunikáció) }\end{array}$ \\
\hline $\begin{array}{l}\text { A programnyelvek, a } \\
\text { kódolás és az } \\
\text { algoritmusok alapvető } \\
\text { elveinek, céljainak és } \\
\text { alkalmazásainak ismerete. }\end{array}$ & $\begin{array}{l}\text { A web alapvetö } \\
\text { szerkezetének megértése } \\
\text { és az online olvasás } \\
\text { hatásainak, müködésének } \\
\text { megértése. }\end{array}$ & $\begin{array}{l}\text { A magánélet és a digitális } \\
\text { én védelmének megóvása } \\
\text { digitális eszközök és } \\
\text { tudatos viselkedés révén. }\end{array}$ \\
\hline $\begin{array}{l}\text { összeállítás (Compose) } \\
\text { (21. századi készségek: } \\
\text { problémamegoldás, } \\
\text { kommunikáció) }\end{array}$ & $\begin{array}{l}\text { szintetizálás (Synthesize) } \\
\text { (21. századi készségek: } \\
\text { problémamegoldás, } \\
\text { kommunikáció) }\end{array}$ & $\begin{array}{l}\text { hozzáférhetővé tétel } \\
\text { (Open-practice) } \\
\text { (21. századi készségek: } \\
\text { kreativitás, } \\
\text { problémamegoldás, } \\
\text { kollaboráció) }\end{array}$ \\
\hline $\begin{array}{l}\text { Online tartalmak } \\
\text { szervezése és megosztása, } \\
\text { licenszek kezelése, online } \\
\text { tartalmak etikai elvei. }\end{array}$ & $\begin{array}{l}\text { Az önálló és egyedi } \\
\text { információk több online } \\
\text { forrásból történö } \\
\text { egyesitése. }\end{array}$ & $\begin{array}{l}\text { A webes források } \\
\text { alkalmazása a mindenki } \\
\text { számára biztositott } \\
\text { hozzáférhetöség és } \\
\text { átláthatóság érdekében. }\end{array}$ \\
\hline
\end{tabular}




\begin{tabular}{|c|c|c|}
\hline $\begin{array}{l}\text { átdolgozás (Revise) } \\
\text { (21. századi készségek: } \\
\text { kreativitás, } \\
\text { problémamegoldás) }\end{array}$ & $\begin{array}{l}\text { értékelés(Evaluate) } \\
\text { (21. századi készség: } \\
\text { problémamegoldás) }\end{array}$ & $\begin{array}{l}\text { közremüködés } \\
\text { (Contribute) } \\
\text { (21. századi készségek: } \\
\text { kreativitás, } \\
\text { problémamegoldás, } \\
\text { kollaboráció) }\end{array}$ \\
\hline $\begin{array}{l}\text { A digitális tartalmak } \\
\text { szisztematikus ellenőrzése } \\
\text { és vizsgálata a } \\
\text { munkafolyamat és a } \\
\text { produktum javitása } \\
\text { érdekében. }\end{array}$ & $\begin{array}{l}\text { Az online forrásokból } \\
\text { származó információk } \\
\text { összehasonlitása és } \\
\text { értékelése relevancia és } \\
\text { hitelesség alapján. }\end{array}$ & $\begin{array}{l}\text { A helyben vagy globálisan } \\
\text { bekapcsolódó tanulók } \\
\text { csoportja, akik úgy érik el } \\
\text { a kívánt közös tanulási } \\
\text { eredményt, hogy közben } \\
\text { online tanulnak és a } \\
\text { virtuális térben } \\
\text { összekapcsolódnak. }\end{array}$ \\
\hline $\begin{array}{l}\text { újraszervezés (Remix) } \\
\text { (21. századi készségek: } \\
\text { kreativitás, } \\
\text { problémamegoldás, } \\
\text { kommunikáció) }\end{array}$ & & $\begin{array}{l}\text { megosztás (Share) } \\
\text { (21. századi készségek: } \\
\text { kreativitás, } \\
\text { kommunikáció) }\end{array}$ \\
\hline $\begin{array}{l}\text { A tartalmak létrehozása és } \\
\text { értelmezése; az online } \\
\text { tartalom megszerkesztése, } \\
\text { átszervezése és } \\
\text { újrafelfedezése révén. }\end{array}$ & & $\begin{array}{l}\text { A digitális tartalmakhoz és } \\
\text { állományokhoz való } \\
\text { hozzáférés megadása a } \\
\text { szerzői jog és a licenszek } \\
\text { figyelembevételével, az } \\
\text { online térben. }\end{array}$ \\
\hline
\end{tabular}

A webműveltség sztenderdje esetében megállapíthatjuk, hogy a digitális állampolgárság kompetenciamodell egyfajta leképezéséről van szó, amely számos elemet átemel az információs műveltségből. Az, hogy a sztenderd egy tudásbázissal, tehát feladatokkal és jó gyakorlatokkal is kiegészül, nagyban segíti a további fejlesztést és az adaptációt.

\section{A 21. században elvárt alapkészségek új értelmezései}

Az elmúlt évtizedben több olyan modell látott napvilágot (lásd 3. táblázat), amely az új alapkészségek, elvárt kompetenciák rendszerét vázolta fel vagy foglalta keretbe abból a célból, hogy az eredményes tanuláshoz és a munkavállaláshoz nélkülözhetetlen készségek körét meghatározza a digitális technológiák világában. (7. táblázat) Számos kutatás foglalkozik a versenyképes, 21. századi képességprofil elemeivel, többek között az Európai Bizottság által a felsőoktatás számára elkészített Digitális Transzformáció (Digital Transform) cselekvési terv 
és a DIGCOMP 2013 digitális kompetenciarendszer modellje, illetve az ISTE digitális állampolgárság ${ }^{22}$ kompetenciarendszere (Ribble, 2011). Hasonló törekvés fogalmazódott meg az UNESCO által 2008-ban, az információs müveltség (Catts, 2008) keretében tárgyalt kommunikációs képességek konstellációjában, de a legegzaktabb összefoglalást a Világgazdasági Fórum (World Econmic Forum) 2015-ben deklarált modelljében érhetjük tetten.

${ }^{22}$ A nemzetközileg elfogadott digitális állampolgárság modell (ISTE-Ribble, 2011; OlléLévai és mtsai, 2014) több elméletet szintetizálva (Mossberger, Tolbert és McNeal), az International Society for Technology in Education (ISTE) által került kidolgozásra és az alábbi kompetenciákat tartalmazza: digitális hozzáférés, digitális műveltség, digitális kommunikáció, digitális felelősség, digitális etikett, digitális biztonság, digitális kereskedelem, digitális jog, digitális egészség és közérzet (Ribble, 2011). 


\section{3. táblázat A 21. századi képességekkel foglalkozó modellek országok/szervezetek szerinti bontásban}

(Binkley, Erstad, Herman, Raizen és Ripley, 2010)

\begin{tabular}{|c|c|c|}
\hline $\begin{array}{l}\text { Ország / Régió/ } \\
\text { Szervezet }\end{array}$ & Dokumentum & Év \\
\hline \multirow[t]{3}{*}{ Európai Unión $^{23}$} & $\begin{array}{l}\text { Az élethosszig tartó tanulás kulcskompetenciái - Európai } \\
\text { Referencia Keretrendszer (Recommendation of the } \\
\text { European Parliament and of the Council of } 18 \text { December } \\
2006 \text { on key competences for lifelong learning.) }\end{array}$ & 2004 \\
\hline & $\begin{array}{l}\text { Az Európai Parlament és Bizottság 2006. december 18-i } \\
\text { ajánlása az élethosszig tartó tanulás } \\
\text { kulcskompetenciáihoz } \\
\text { (Recommendation of the European Parliament and of the } \\
\text { Council of } 18 \text { December } 2006 \text { on key competences for } \\
\text { lifelong learning.) }\end{array}$ & 2006 \\
\hline & $\begin{array}{l}\text { „Oktatás és képzés 2010” program implementálása } \\
\text { (Implementation of “Education and Training 2010” Work } \\
\text { Programe) }\end{array}$ & 2010 \\
\hline Egyesült Államok & $\begin{array}{l}\text { P21 keretrendszer }{ }^{24} \text { (Partnerség a 21. századi } \\
\text { képességekért modellje a 21. századi tanulásról) }\end{array}$ & 2008 \\
\hline Ausztrália $^{25}$ & $\begin{array}{l}\text { Melburni deklarátum a fiatal ausztrálok oktatási céljaiért } \\
\text { (Melbourne declaration on educational goals for young } \\
\text { Australians) }\end{array}$ & 2008 \\
\hline Skócia $^{26}$ & $\begin{array}{l}\text { Kiválóságok tananyaga : tananyagkészítés a négy } \\
\text { képesség, a tanulás, az élet és a munka fejlesztéséhez } \\
\text { (Curriculum For Excellence: Building The Curriculum } 4 \\
\text { Skills For Learning, Skills For Life And Skills For Work) }\end{array}$ & 2009 \\
\hline \multirow{2}{*}{$\begin{array}{l}\text { Egyesült Államok. } \\
\text { Department of } \\
\text { Labor. } \\
\text { National } \\
\text { Academies, science } \\
\text { for the 21st century }\end{array}$} & $\begin{array}{l}\text { Kompetenciamodllek. Ennis, R. Michelle (2008). } \\
\text { Competency models: a review of the literature The role of } \\
\text { the Employment and Training Administration (ETA). }{ }^{27}\end{array}$ & 2008 \\
\hline & $\begin{array}{l}\text { A tudomány, az oktatás és a fejlesztés kapcsolódási } \\
\text { pontjainak feltárása a } 21 \text {. századi képességek mentén } \\
\text { (Kolodner, J. L. Exploring the Intersection of Science } \\
\text { Education and the Development of } 21 \text { st Century } \\
\text { Skills.) }{ }^{28}\end{array}$ & 2010 \\
\hline $\begin{array}{l}\text { ATC (Assessment } \\
\text { and Teaching of } \\
\text { 21st Century } \\
\text { Skills) }\end{array}$ & $\begin{array}{l}\text { Binkley, Erstad, Herman, Raizen, Ripley és Rumble ( } \\
\text { 2010): Draft White Paper } 1 . \text { Defining } 21 \text { st century } \\
\text { skills. }\end{array}$ & 2010 \\
\hline
\end{tabular}

\footnotetext{
${ }^{23}$ URL: https://goo.gl/xGvB0H (utolsó megtekintés: 2016. szeptember 10.)

${ }^{24}$ URL: https://goo.gl/r4GANK (utolsó megtekintés: 2016. szeptember 10.)

${ }^{25}$ URL: https://goo.gl/zvEVYP (utolsó megtekintés: 2016. szeptember 10.)

${ }^{26}$ URL: https://goo.gl/hpYD8m (utolsó megtekintés: 2016. szeptember 10.)

${ }^{27}$ URL: https://goo.gl/JcErG2 (utolsó megtekintés: 2016. szeptember 10.)

${ }^{28}$ URL: https://goo.gl/000gSh (utolsó megtekintés: 2016. szeptember 10.)

${ }^{29}$ URL: https://goo.gl/upd1F5 (utolsó megtekintés: 2016. szeptember 10.)
} 


\begin{tabular}{|c|c|c|}
\hline $\begin{array}{l}\text { Ország / Régió/ } \\
\text { Szervezet }\end{array}$ & Dokumentum & $\overline{\mathbf{E} \mathbf{v}}$ \\
\hline $\mathrm{OECD}^{30}$ & $\begin{array}{l}\text { Új évezred tanulói projekt: az IKT és a tanulás kihívásai } \\
\text { (Centre for Educational Research and Innovation (CERI) } \\
\text { - New Millennium Learners) }\end{array}$ & $\begin{array}{c}2010- \\
2012\end{array}$ \\
\hline $\begin{array}{l}\text { NAEP (National } \\
\text { Assessment of } \\
\text { Educational } \\
\text { Progress) } \\
\end{array}$ & $\begin{array}{l}\text { Griffin,P.; McGaw, B.; és Care, E. (szerk.) (2012) } \\
\text { Assessment and Teaching of 21 st Century Skills. }{ }^{31}\end{array}$ & 2012 \\
\hline $\begin{array}{l}\text { (Davidson, 2012) } \\
\text { (Davidson és } \\
\text { Goldberg, 2010) } \\
\end{array}$ & $\begin{array}{l}\text { Teaching the fourth "r:" webmaking as a vital } 21 \mathrm{st} \\
\text { century skill. 4R modell }{ }^{32}\end{array}$ & 2012 \\
\hline $\begin{array}{l}\text { ITL-Innovative } \\
\text { Teaching and } \\
\text { Learning }\end{array}$ & $\begin{array}{l}\text { 21. századi kompetenciák és tanulási stílusok. } \\
\text { 21st Century Learning Design, formerly called } \\
\text { 'LEAP21'33 }\end{array}$ & 2012 \\
\hline \multirow[t]{2}{*}{ Anglia $^{34}$} & $\begin{array}{l}\text { The learning journey England Personal learning \& } \\
\text { thinking skills }\end{array}$ & 2013 \\
\hline & $\begin{array}{l}\text { Angliai nemzeti tanterv-The national curriculum for } \\
\text { England }\end{array}$ & 2013 \\
\hline ISTE & $\begin{array}{l}\text { National educational technology standards for students, } \\
\text { second edition, global learning in the digital age }\end{array}$ & $\begin{array}{l}2008 \\
2014\end{array}$ \\
\hline
\end{tabular}

Ezek közül jelen kutatásban a P21, azaz Partnerség a 21. századi képességekért modellje a 21 századi tanulásról (2008); az UNESCO által meghatározott kommunikációs készség térkép (Catts és Lau, 2008), valamint a Világgazdasági Fórum (World Economic Forum, 2015) új alapkészségek modelljét ismertetem. Azért tartom ezeket kiemelt jelentőségünek, mert egyrészt mindegyikük olyan szemléletet képvisel a tanulás új rendszeréről, amely előmozdította a későbbi innovációkat, másrészt szerkezetükben egymástól jelentősen különböznek, harmadrészt a szakirodalmak alapján a leggyakrabban idézett modellekről van szó. Mindegyikük esetében olyan rendszert ismerthetünk meg, amely a digitális átállás módszertani aspektusából nagy jelentőséggel bír.

\section{P21, azaz Partnerség a 21. századi képességekért modellje a 21 századi tanulásról (2008)}

A holisztikus szemléletet követő tanulási modell az Egyesült Államok K12 korosztálya számára fogalmazza meg azokat az elvárásokat, készségeket és

\footnotetext{
${ }^{30}$ URL: https://goo.gl/hDPW3d (utolsó megtekintés: 2016. szeptember 10.)

${ }^{31}$ URL: https://goo.gl/y0Io8N (utolsó megtekintés: 2016. szeptember 10.)

${ }^{32}$ URL: https://goo.gl/oN7RDj (utolsó megtekintés: 2016. szeptember 10.)

${ }^{33}$ URL: https://goo.gl/7fGMXc (utolsó megtekintés: 2016. szeptember 10.)

${ }^{34}$ URL: https://goo.gl/YdbZCF (utolsó megtekintés: 2016. szeptember 10.) URL: https://goo.gl/X0RAvT (utolsó megtekintés: 2016. szeptember 10.)
} 
képességeket, amelyekre minden diáknak szüksége van az Egyesült Államokban (is).

A modell komponensei rendszert alkotnak; nem egymástól elzártan müködnek, hanem egymást kiegészítve $(A S C D, 2009)$. Az is fontos szempont a fejlesztők szerint, hogy az akadémiai közeg bevonásával kell a fejlesztést elvégezni és a 21. századi tanulást új alapokra helyezni. Nagy jelentőséggel bírnak tehát: a megfelelő tanulási környezet(ek) kialakítása, a szakmai fejlesztés, a tanterv szintü stratégia meghatározása, valamint a hazai és nemzetközi standardok és mérések (22. ábra).

A modell elemei közé tartozik az a tanulási környezet, ${ }^{35}$ amelyben a megfelelő oktatási célkitüzésekhez igazodva a tanulás-tanítás folyamata (formális, nem formális, informális módon) végbemegy, és az eszköz másodlagos szerepet tölt be. Hangsúlyozottan megjelenik, hogy a tanulási környezet (iskola, osztályterem, könyvtár, virtuális tér) nem csak egy hely(szín), hanem olyan támogató rendszer, amely a tanuló egyedi igényeihez ${ }^{36}$ alkalmazkodva támogatja az egyéni és társas tudáselsajátítást, illetve magában foglalja a tanulás-tanítás szerkezetét, az eszközt és a tanulóközösséget a tanulók és a tanárok számára egyaránt. ${ }^{37}$

A 21. században a tanulási környezet egy szinergikus rendszer, amely:

${ }^{35}$ A tanulási környezet definícióján a Nahalka (2002), illetve a Brown és Collins (1992) által definiált fogalmat értjük. Nahalka (2002): ,A tanulási környezet azt a gondolatilag egységes, határozott elméleti alapokon nyugvó, a tanulási folyamatot befolyásoló összes fontos tényezőt magába integráló rendszert jelenti, amelynek keretei között a valóságos iskolai tanulás végbemegy" (Nahalka, 2002. 66. o.).

Brown és Collins (1992): a hatékony tanulási környezet a tanulásban, gondolkodásban és problémamegoldásban való jártasságra irányuló diszpozíció kialakulását elősegítő oktatási környezet, amely képes az ehhez szükséges elsajátítási folyamatok életre hívására és fenntartására (Zoller, 2011. 57. o.)

Az elektronikus tanulási környezet definíciói közül a Komenczi (2008) által megfogalmazottat tekintjük irányadónak, aki - gyüjtőfogalomként használva a terminológiát - az alábbiakat érti alatta: „olyan tanulási környezeteket jelent, ahol a tanitás és tanulás feltételrendszerének kialakitásánál meghatározó szerepe van az elektronikus információ- és kommunikációtechnikai eszközöknek” (Komenczi, 2009, 114. o., idézi Papp-Danka, 2011) Igaz azonban, hogy a terminológiában nincs teljes konszenzus, hiszen ahogyan Papp-Danka (2011) is kiemeli, a digitális környezetet alkalmazó tanulási környezet számos (fogalom)változata figyelhető meg a szakirodalomban.

${ }^{36}$ A személyes tanulási környezet (PLE) éppen e szempont alapján jó alternatíva.

${ }^{37}$ Ahogyan Nahalka (2002. 65. o.) is kiemeli, a pedagógus feladata egy olyan környezet megteremtése, amely elösegítheti a folyamat kibontakozását és hatékonyságát. Az oktatáselmélet effajta megközelítése a tanulási környezetek kialakításában gondolkodik, amely folyamatot és annak összetevőit is integrálni tudja (Zoller, 2011. 57. o.) 
- olyan tanítási helyzeteket/gyakorlatot, fizikai környezetet és humánerőforrást alkalmaz, amely támogatja a 21 . századi készségek eredményes fejlesztését.

- Támogatja a tanulóközösségeket, lehetővé teszi az oktatók kollaborációját a jó gyakorlatok megosztása érdekében.

- Lehetővé teszi a tanulóknak a valós, 21. századi módszerekkel történő tanulást (például projektmódszerrel).

- Egyenlő hozzáférést biztosít a tanulási eszközökhöz, technológiákhoz és erőforrásokhoz (beleértve a tudásbázisokat is).

- Csoportos, team- és egyéni tanulást elősegítő tereket és módszereket használ.

- Támogatja a kiterjesztett tanulási tereket, a hazai és nemzetközi közösségekben való tanulást személyes és online formában egyaránt.

A modellben az alapkészségek (3R) között jelenik meg az angol nyelv, az olvasás és írás (nyelvi művészet), ${ }^{38}$ a matematika, a természettudomány, az idegen nyelvek, az állampolgári és gazdasági ismeretek; továbbá a müvészetek, a történelem és földrajz. Ezen túlmutató ismeretek a kritikai gondolkodás és a problémamegoldás, a kommunikáció, az együttmüködés, valamint a kreativitás és az innovációs készség (4Cs).

${ }^{38}$ Az English, reading or language arts kifejezésre nincs egzakt magyar fordítás. A nyelvi művészet fordítást alkalmaztam, amely tartalmában a magyar nyelv és irodalom tantárgyhoz illeszkedik leginkább. 


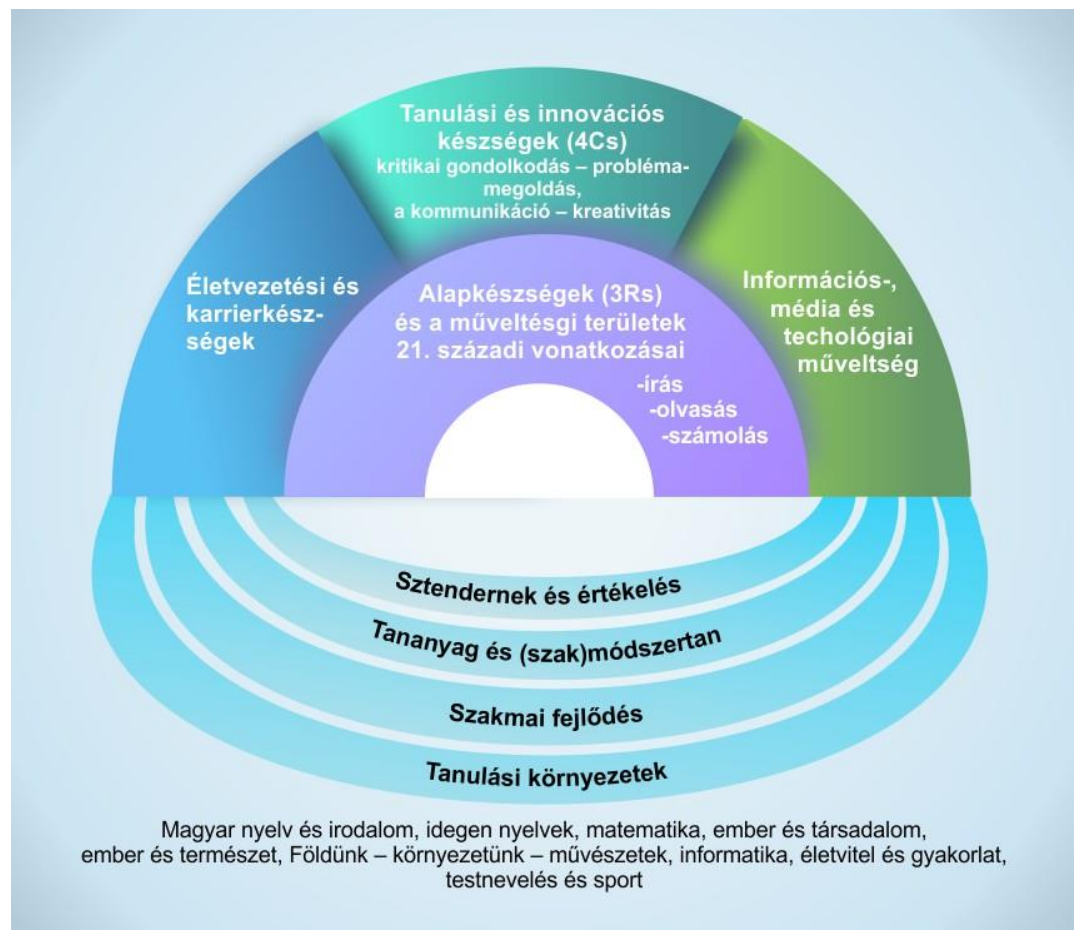

6. ábra A 21. századi tanulás keretrendszere a Partnerség a 21. századi képességekért szervezet szerint

(Partnership for 21st Century Learning. Framework for 21st Century Learning, 2014)

URL: https://goo.gl/CG1gbL

Az ún. „kemény készségek” (hard skills), azaz alapvető matematikai és problémamegoldó készségek mellett hangsúlyossá válnak az ún. „puha készségek" is: csoportmunka, szóbeli és írott prezentáció, illetve ezek fejlesztése minél magasabb szintü digitális környezetben (Murnane és Levy, 1996). Alapvető tényezővé válik tehát a kreativitás fejlesztése, vagyis a tanulók fejlett vizuális képességeinek kiaknázása; a tudatos és kritikus médiahasználat, valamint az immunokompetencia, tehát a problémák rugalmas megoldásának keresése vagy a dinamikus problémakezelés minél magasabb szintủ képességének alkalmazása. ${ }^{39}$ Fontos szerepet kap tehát a kreatív problémamegoldáshoz szükséges közeg kialakítása.

${ }^{39}$ A kutatási eredmények ugyanis mutatják, hogy az iskolában megtanult ismeretek a mindennapi életben nehezebben transzferálhatók, és hátterében többek között a hazai szigetszerü oktatási módszerek, valamint elszigetelt ismeretelemek állnak. A problémamegoldás újfajta modellje - a PISA műveltségkoncepcióját $(O E C D, 2010)$ beleszőve - tíz éve készült el. 
Ezek az elvárások azonban csak akkor valósulhatnak meg, ha a pedagógusok aktív részesei lesznek a digitális átalakításnak, valamint célzott, tervszerü képzésük és továbbképzésük az oktatási folyamat részévé válik.

\section{UNESCO kommunikációs készségtérkép}

Az UNESCO által megalkotott kommunikációs készségek térképén (Catts és Lau, 2008. 18. o.) az egymásra épülő gondolkodási készségek és az alapmüveltségi területek alkotta szintekben jelenik meg egy-egy írástudásforma (bővebben lásd Z. Karvalics, 2012); a térképen az információs müveltséget tekinthetjük a legmagasabb szinten állónak. Az információs és kommunikációs technológiai (IKT-) és a médiaműveltség meglétét feltételezi ez a szint, amely a digitális technológiát, a hálózatot, valamint a tudatos és kritikus médiahasználatot tekinti a föbb komponensnek.

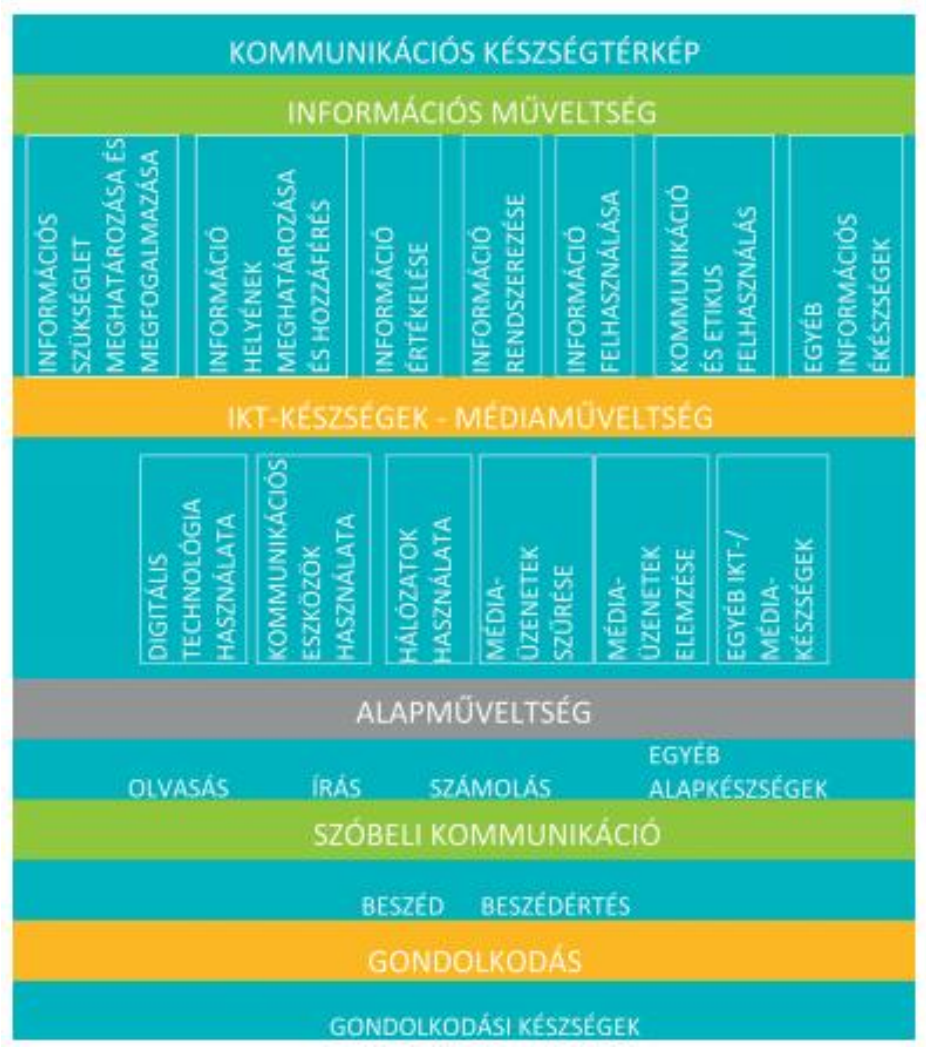

7. ábra Az UNESCO által meghatározott kommunikációs készségtérkép (TurcsányiSzabó és Abonyi-Tóth, 2015. 12. o.) 
A modellben megjelenik a korábban említett technológiai tudás fontossága, amelyet az IKT-készség és médiaműveltség kategóriáknál érhetünk tetten. Ennél magasabb szint az információs müveltség szintje, amely már feltételezi az előzőek meglétét és magasabb szintű készségeket foglal magában, úgy mint az információ iránti igény megjelenése, az információval kapcsolatos műveletek és a kritikai értékelés.

\section{21. századi alapkészségek (World Economic Forum)}

A Világgazdasági Fórum 2015-ben határozta meg az új alapkészségek rendszerét, amelyben a 21. századi jártasságok három fö területen helyezkednek el az élethosszig tartó tanulás tengelyén:

- Alapmüveltségi elemek: amelyek alapján a tanulók az alapvető jártasságokat alkalmazzák a mindennapi tevékenységek szerint.

- Kompetenciák: amelyek alapján a tanulók meg tudnak felelni a komplex kihívásoknak.

- Személyes tulajdonságok/személyiségjegyek: a tanulók megküzdését segítik a változó környezetben.

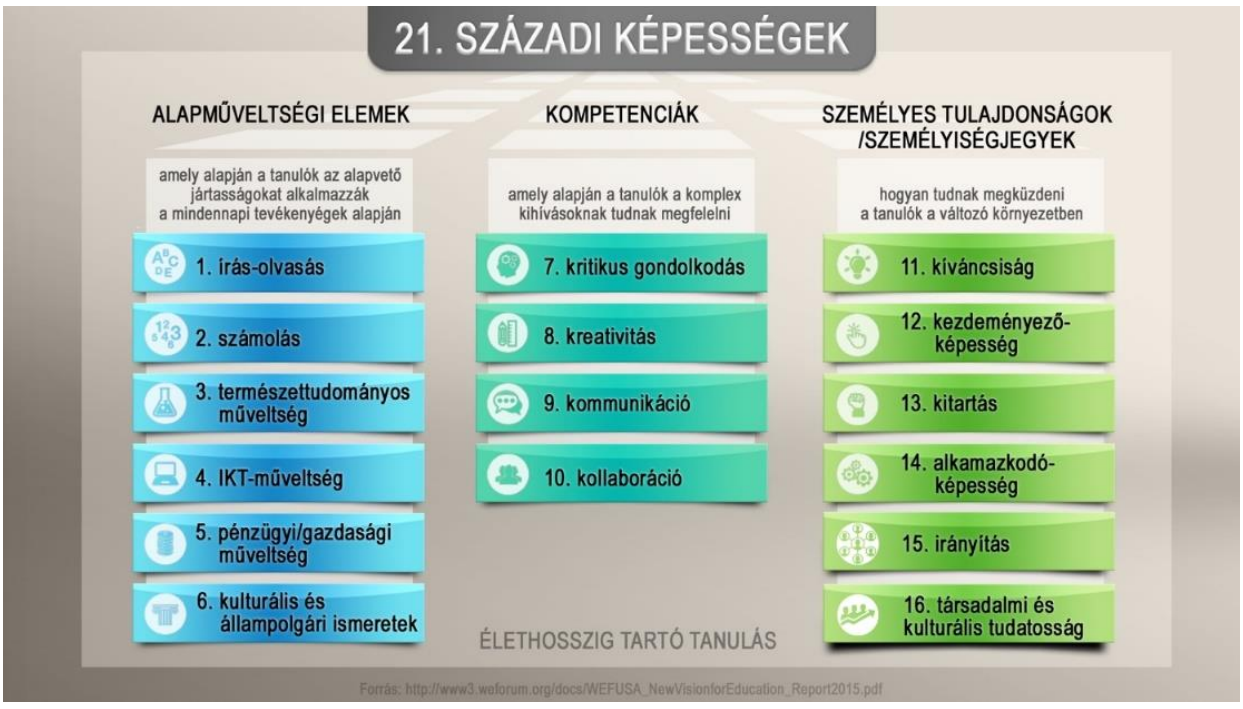

8. ábra 21. századi képességek konstellációja (saját fordítás) ${ }^{40}$

(World Economic Forum, 2015)

\footnotetext{
${ }^{40}$ Mindhárom területhez kapcsolódik egy leírás, hogy az adott készség/képesség alatt mit értenek:
} 
A fenti modellben az alapkészségek között szerepel az IKT-müveltség, ami bár jelentős elörelépést jelent, eredményesebb lenne, ha minden területre beépülne és nem egy különálló területet jelentene. Ennek oka, hogy a hazai pedagógus professzió kompetenciarendszere is a jelen modellben bemutatott megoldást alkalmazta, hasonlóan a Nemzeti Alaptantervhez, ami azt eredményezi, hogy nem integrálódik más területekbe az IKT-müveltség, hanem például egy-egy diszciplína vagy tantárgy számára teszik fejlesztési feladattá.

Az is látható azonban, hogy ennél a képességnél lényegében az információs müveltség elemei jelennek meg, hiszen a fejlesztők definíciója szerint: az IKTmüveltség a technológia által meghatározott platformon lévő tartalmak létrehozásának és használatának képessége, amelynek része az információ

\footnotetext{
Alapmüveltség-elemek:

1. Írás-olvasás: az írott nyelv olvasásának, megértésének használatának képessége.

2. Számolás: a számok használatának és egyéb jeleknek/szimbólumoknak a megértése, a számszerü (kvantitatív) kapcsolatok kifejezése.

3. Természettudományos müveltség: a természettudományos tudás és elvek megértése a saját környezetben, hipotézisek tesztelése.

4. IKT-müveltség: a technológia alapú tartalmak létrehozásának és használatának képessége, amelynek része az információ megtalálása és megosztása, a kérdések megválaszolása, a másokkal való kommunikáció és a számítógépes programozás.

5. Pénzügyi/gazdasági müveltség: a pénzügyek számszerü anyagi vonzatának megértése és alkalmazása.

6. Kulturális és állampolgári ismeretek: megérteni, elfogadni, elemezni és alkalmazni az humán tőkével kapcsolatos ismereteket.
}

\section{Kompetenciák:}

7. Kritikus gondolkodás és problémamegoldás: a helyzetek megértésének, elemzésének és értékelésének képessége, a megoldási alternatívák és ötletek kifejezése.

8. Kreativitás: innovatív megoldások elképzelése és kidolgozása adott probléma kapcsán, kérdések megválaszolása, vélemény kifejezése; a meglévő tudáselemek alkalmazása, szintézise és újbóli alkalmazása.

9. Kommunikáció: információk meghallgatása, megértése, közvetítése és kontextualizálása verbális, nonverbális, vizuális és írott formában.

10. Kollaboráció: a csapatban való munka képessége egy közös cél érdekében, a konfliktusok megelőzésének és kezelésének képességével.

\section{Személyes tulajdonságok/személyiségjegyek:}

11. Kíváncsiság: a kérdések megválaszolása iránti igény képessége; a széles látókör, nyitottság és befogadóképesség megmutatása.

12. Kezdeményezőképesség: az új feladatokhoz való proaktív hozzáállás képessége.

13. Kitartás: a kitartó érdeklödés és siker képessége egy adott cél elérése érdekében.

14. Alkalmazkodóképesség: tervek, módszerek, vélemények és célok megváltoztatásának képessége az új információk birtokában.

15. Irányítás: a hatékony, direkt irányítás képessége egy közös cél érdekében.

16. Társadalmi és kulturális tudatosság: interakció más emberekkel társadalmi, kulturális és etikai értelemben. 
megtalálása és megosztása, kérdések megválaszolásában a másokkal való kommunikáció és a számítógépes programozás. Érdekes jelenség, hogy korábban a programozás és ezzel együtt az algoritmikus gondolkodás nem került a kiemelt területek közé, pedig fejlesztésük szükségszerü lenne. ${ }^{41}$

41 Ahogyan ez hazánkban az informatika tantárgy és az IKT-digitális kompetencia fejlesztése esetében történt. 


\section{Irodalomjegyzék}

ASCD (2009): Four Phases of Implementation. In: https://www.slideserve.com/astro/four-phases-of-implementationjacobs-and-johnson-ascd-2009 (utolsó megtekintés: 2020. január 10)

Binkley, M., Erstad, O., Herman, J., Raizen, S., Ripley, M. és Rumble, M. (2010). Defining 21st century skills. Cisco, Intel, Microsoft: Assessment and Teaching of 21 st Century Skills project draft White Papers. The University of Melburne. https://doi.org/10.1007/978-94-007-2324-5_2

Catts, R. és Lau, J. (2008): Towards Information Literacy Indicators. Conceptual framework paper. UNESCO, Paris

DIGCOMP (2013). A Framework for Developing and Understanding Digital Competence in Europe, 2013.

Farkas Bertalan Péter (2016). Digitális intelligencia: Készségek a sikeres digitális élethez.

URL: https://goo.gl/bdMr13 (utolsó megtekintés: 2020. január 10.)

Ferrari, A.(2013). DIGCOMP: A Framework for Developing and Understanding Digital Competence in Europe. Brüsszel: European Commission

Hunya Márta (2013). A fiatalok felkészitése a tudás alapú társadalomban való részvételre. Budapest: Oktatáskutató és fejlesztő Intézet. URL: https://goo.gl/xSqeop(utolsó megtekintés: 2020. január 10.)

Hunya Márta (2016). A tanulás támogatása a digitális korszakban. A digitálisan kompetens oktatási intézmények európai keretrendszere. In: Melléklet a digitális és online munkacsoport eredményei címü tanulmányhoz. Budapest: Tempus Közalapítvány. URL: https://goo.gl/9Dsnnz (utolsó megtekintés: 2020. január 10.)

Hunya Márta (2016b). Digitális és online tanulás. In: Széll Krisztián (szerk.) $A z$ Európai Unió az oktatásról: stratégiai irányok és értelmezések. 33-40. Budapest: Oktatáskutató és Fejlesztő Intézet.

IKER (2016). IKER, azaz az Infokommunikációs Egységes Referenciakeret fogalomtár. 
IKER (2016b). Az IKER önértékelö és referenciakeret 4 szintjének tartalma. IKER társadalmasitás workshop. Budapest, 2016. április 12. URL: https://goo.gl/uzDIt1 (utolsó megtekintés: 2016. szeptember 10.)

Karvalics László, Z. (2012). Információs kultúra, információs műveltség - egy fogalomcsalád értelme, terjdedelme, tipológiája és története. Információs társadalom. 12. 1. URL: https://goo.gl/jvlfBe (utolsó megtekintés: 2020. január 10.)

Komenczi Bertalan (2009). Elektronikus tanulási környezet. Budapest: Gondolat Kiadó. Kognitív szeminárium sorozat.

Mossberger, K., Tolbert, C. J., \& McNeal, R. S. (2007). Digital citizenship: The Internet, society, and participation. MIt Press. https://doi.org/10.7551/mitpress/7428.001.0001

Murnane, R.J. és Levy, F. (1996). Teaching the New Basic Skills: Principles for Educating Children to Thrive in a Changing Economy. New York: Martin Kessler Books, Free Press.

Nahalka István (2002). Hogyan alakul ki a tudás a gyermekekben? Konstruktivizmus és pedagógia. Budapest: Nemzeti Tankönyvkiadó.

OECD (2010): Education at a Glance 2010: OECD Indicators. In: http://www.oecd.org/education/skills-beyondschool/educationataglance2010oecdindicators.htm (utolsó megtekintés: 2020. január 10)

Ollé János, Lévai Dóra, Domonkos Katalin, Szabó Orsi, Papp-Danka Adrienn, Czirfusz Dóra, Habók Lilla, Tóth Renáta, Takács Anita, Dobó István(2014): Digitális állampolgárság az információs társadalomban. Budapest, Eötvös Kiadó, 2014

P21 (2014). Partnership for 21st Century Learning. Framework for 21st Century Learning, 2014.

URL: https://goo.gl/uldvRa (utolsó megtekintés: 2020. január 10.)

Papp-Danka Adrienn (2011). Az online tanulási környezet fogalmának értelmezési lehetőségei. Oktatás-informatika. 12. 1-6.

Prensky, M. (2001). Digital Natives, Digital Immigrants, Part 1. On the Horizon, NCB University Press 9.5. URL: https://goo.gl/K5cJRR (utolsó megtekintés: 2020. január 10.) https://doi.org/10.1108/10748120110424816 
Ribble, M. (2011). Digital Citizenship in Schools. Second Edition. International Society for Technology in Education. Oregon, Washington, D.C.: Eugene.

Ribble, Mike ( 2011) Digital citizenship in schools ISTE \& Eurospan (London) ISBN 978-156484-301-2 166 p. URL:

http://www.iste.org/store/product.aspx?ID=2111 (utolsó megtekintés: 2020. január 10)

Turcsányi-Szabó Márta és Abonyi-Tóth Andor. (2015). A digitális irástudás fejlesztésének lehetőségei. Budapest: Educatio Társadalmi Szolgáltató Nonprofit Kft.

World Economic Forum (2015). New Vision for Education Unlocking the Potential of Technology. Prepared in collaboration with The Boston Consulting Group 32.

URL: https://goo.gl/fG5Yym (utolsó megtekintés: 2020. január 10.)

World Economic Forum (2015). New Vision for Education Unlocking the Potential of Technology. Prepared in collaboration with The Boston Consulting Group 32.

URL: https://goo.gl/fG5Yym (utolsó megtekintés: 2020. január 10.)

Yuhyun, Park (2016) 8 digital skills we must teach our children. World Econmic Forum. https://www.weforum.org/agenda/2016/06/8-digital-skills-wemust-teach-our-children/

Zoller Katalin (2011). Tanulási környezet az alkalmazott oktatáskutatásban. PedActa. 1. 1-2. 53-64. 